\title{
NUMERICAL STUDY OF THERMAL CHARACTERISTICS OF FUEL OIL-ALUMINA AND WATER-ALUMINA NANOFLUID FLOW IN A CHANNEL IN THE LAMINAR FLOW
}

\author{
Hossein Fatahian ${ }^{*}$, HeSAMOddin SAlarian ${ }^{1}$, MAJID Eshagh NimVARI ${ }^{2}$ \\ AND ESMAEEL FATAHIAN ${ }^{1}$ \\ ${ }^{I}$ Department of Mechanical Engineeing, Nour Branch, Islamic Azad University, Nour, Iran \\ ${ }^{2}$ Faculty of Engineeing, Amol University of Special Modern Technologies, Amol, Iran. \\ *Corresponding author: fatahianhossein@gmail.com
}

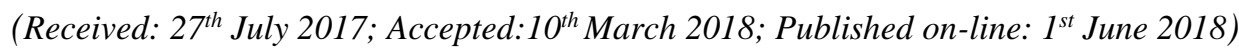

https://doi.org/10.31436/iiumej.v19i1.857

\begin{abstract}
The present study investigated the thermal effects of the use of nanoparticles in the fuel-oil and water-based fluids, as well as the numerical simulation of laminar flow of fuel-oil-alumina and the water-alumina nanofluids in a channel. A second order discretization method was used for solving equations and a SIMPLE algorithm was applied for pressure-velocity coupling using Fluent. Effect of nanoparticle volume fraction and particles size in different Reynolds numbers $(900 \leq \operatorname{Re} \leq 2100)$ on the convective heat transfer coefficient was studied. The simulation was conducted for three different volume fractions and particle sizes in the laminar flow under constant heat flux. The results showed that adding nanoparticles to the base fluid caused an increase in the thermal conductivity ratio of the fluid, which was observed to a greater degree in the fuel oil-alumina nanofluid than in the water-alumina nanofluid. The increase in nanoparticle volume fraction caused an increase in the convective heat transfer coefficient and the Nusselt number of the nanofluids. The significant point of this study was that in the same volume fraction, the effect of adding alumina nanoparticles to the fuel-oil-based fluid had more effect than adding these particles to water-based fluid, while the effect of increasing the Reynolds number in the water-alumina nanofluid on convective heat transfer coefficient was greater than the fuel-oil-alumina. Also, in the same Reynolds number and volume fraction with increasing size of nanoparticles, the value of the convective heat transfer coefficient was decreased. The results of this study can be used in refineries and petrochemical industries where the fuel-oil fluid flows in the channels.
\end{abstract}

ABSTRAK: Kajian ini adalah bagi mengkaji kesan haba terhadap penggunaan bahan bakar-minyak dan cecair asas-air dalam nanopartikel, juga menjalankan simulasi pengiraan aliran laminar bahan bakar-minyak-alumina dan cecair-nano air-alumina dalam saluran. Kaedah berasingan kelas kedua telah digunakan bagi menyelesaikan persamaan dan algoritma SIMPLE telah diaplikasikan dalam gandingan kelajuan-tekanan menggunakan Fluent. Kesan jumlah pecahan nanopartikel dan pelbagai bilangan saiz zarah dalam bilangan Reynolds $(900 \leq \mathrm{Re} \leq 2100)$ pada pekali pemindahan haba perolakan telah dikaji. Simulasi telah dijalankan pada tiga pecahan isipadu berlainan dan pada zarah dalam aliran laminar dengan fluks haba tetap. Hasil kajian menunjukkan bahawa dengan penambahan nanopartikel dalam cecair-asas menyebabkan peningkatan nisbah daya pengaliran haba cecair pada cecair-nano bahan bakar-minyak-alumina 
melebihi daripada cecair-nano air-alumina. Penambahan pada pecahan isipadu nanopartikel ini menyebabkan peningkatan pada nilai pekali pemindahan haba perolakan dan bilangan Nusselt dalam cecair-nano. Perkara penting dalam kajian ini adalah pada pecahan isipadu sama, kesan penambahan nanopartikel alumina kepada cecair berasaskan minyak mempunyai kesan yang lebih besar daripada penambahan zarah-zarah ini kepada cecair berasaskan air. Pada masa sama, kesan peningkatan bilangan Reynolds dalam cecair-nano air-alumina pada pekali pemindahan haba perolakan lebih besar daripada kesan peningkatan bahan bakarminyak-alumina. Selain itu, pada bilangan Reynolds yang sama dan dengan peningkatan saiz nanopartikel pecahan isipadu, nilai pekali pemindahan haba perolakan turut menurun. Hasil kajian ini boleh digunakan dalam industri penapisan dan petrokimia di mana bahan bakar cecair minyak mengalir dalam saluran.

KEYWORDS: blood rheology; blood rheology; non-newtonian fluids; shear-thinning behavior; thixotropy

\section{INTRODUCTION}

Heat transfer is a vital process in all industries around the world. Low thermal conductivity of conventional heat transfer fluids such as water, oil, and ethylene glycol mixture is a serious limitation in improving the performance and compactness of engineering equipment [1]. Nowadays, new strategies are used in order to improve the effective heat transfer behaviors of such fluids. Using particles of nanometer dimensions in liquids is one of these strategies that led to the production of nanofluids. The term 'nanofluid' refers to a two-phase mixture with the continuous phase generally being a liquid and the dispersed phase constituting 'nanoparticles' i.e. extremely fine metallic particles of size below $100 \mathrm{~nm}$ [2]. Numerous studies have revealed the advantages of nanofluids over base fluids regarding higher thermal conductivity. A theoretical analysis of nanofluid flow was reported by Prasher et al. [3]. They compared the pressure drop of base fluids and nanofluids when the heat transfer coefficient for both fluids was equal. Literature exists [4-10] on single-phase nanofluids forced convection flow in such various geometries as flat plates, circular tubes, noncircular channels, annuli, and cross flow over circular tubes. The previous results have underscored the enhancement of heat transfer due to the presence of nanoparticles in the fluids. Xuan and Li [11] and Xuan and Roetzel [12] have identified two causes of improved heat transfer by nanofluids: the increased thermal dispersion due to the chaotic movement of nanoparticles that accelerates energy exchanges in the fluid and the enhanced thermal conductivity of nanofluids. On the other hand Kelbinski et al. [13] studied four possible mechanisms that contribute to the increase in nanofluid heat transfer: Brownian motion of the particles, molecular-level layering of the liquid/particle interface, heat transport in the nanoparticles, and nanoparticle clustering. Similarly to Wang et al. [14], they showed that the effects of the interface layering of liquid molecule and nanoparticle clustering could provide paths for rapid heat transfer. Pak and Cho [15] investigated the heat transfer performance of $\mathrm{Al}_{2} \mathrm{O}_{3}-\mathrm{g}$ and $\mathrm{TiO}_{2}$ nanoparticles dispersed in water inside a horizontal tube. They observed that an increase in $\mathrm{Re}$ number and particle concentration leads to an increase in $\mathrm{Nu}$ number, but the convective heat transfer coefficient of nanofluid with $3 \%$ volume fraction decreases by $12 \%$ compared to the base fluid. Li et al. [16,17] also experimentally studied the convective heat transfer of $\mathrm{CuO} /$ water nanofluid inside a horizontal tube with constant heat flux in both laminar and turbulent regimes. Their studies showed that the suspended 
nanoparticles enhanced the convectional heat transfer performance of the base fluid. Sankar et al. [18] simulated the variation of the thermal conductivity in nanofluids using a molecular dynamics approach. Zhao et al. [19] concluded that the addition of solid nanoparticles with high thermal conductivity and the phenomenon of micro convection, caused by a nonuniform shear stress in a nanofluids, are the main factors in the enhancement of heat transfer coefficients. Khaled and Vafai [20] investigated the effect of thermal dispersion on heat transfer enhancement of nanofluids. Wen and Ding [21] were first to develop a theoretical model to predict particle migration in pressure-driven laminar pipe flows of relatively dilute nanofluids. They showed that shear induced, viscosity gradient-induced, and concentration gradient-induced particle migration results in the large radial variation of particle distribution, viscosity, and thermal conductivity. Maiga et al. [22] numerically studied the hydrodynamic and thermal behavior of turbulent flow in a tube using the $\mathrm{Al}_{2} \mathrm{O}_{3}$ /water nanofluid under the constant heat flux boundary condition. In their study, a new correlation is proposed to calculate the fully developed heat transfer coefficient for the nanofluid considered. Rostamani et al. [23] simulated the turbulent flow of copper oxide $(\mathrm{CuO})$, alumina $\left(\mathrm{Al}_{2} \mathrm{O}_{3}\right)$, and oxide titanium $\left(\mathrm{TiO}_{2}\right)$ nanofluids with different volume concentrations of nanoparticles flowing through a two-dimensional duct under constant heat flux condition. Their results showed that the $\mathrm{CuO} /$ water and $\mathrm{TiO}_{2} /$ water nanofluids have the highest and lowest shear stress values, respectively, due to the higher viscosity of copper oxide $(\mathrm{CuO})$ in comparison to other nanofluids. Moghari et al. [24] numerically studied the pressure drop and thermal characteristics of $\mathrm{Al}_{2} \mathrm{O}_{3}$-water nanofluid flow in horizontal annuli under constant heat flux boundary conditions applied to both inner and outer walls. They analyzed the effects of nanoparticle volume fraction, heat flux ratio, radius ratio, and Grashof number on heat transfer and showed that Nusselt number increases with the increase of nanoparticle volume fraction, heat flux, radius ratios, and Grashof number. Celik et al. [25] investigated laminar mixed convection in a two dimensional symmetrically and partially heated vertical channel and also noted that Aluminum oxide/water nanofluid was considered as working fluid. Their results showed that the use of nanoparticles in fluid increases heat transfer rate in the channels. Also, the rate of increase depends on both the Reynolds and the Richardson numbers. In this study, two-dimensional laminar flow of fuel-oil-alumina and water-alumina nanofluids in a channel was conducted. The main reason for choosing fuel oil-alumina nanofluid was that nanoparticles are used as additives to engine oils in order to remove more heat from the high heat flux parts of engines [26, 27]. These additives also have shown anti wear and anti-friction characteristics due to their spherical shapes [28]. For this purpose the effect of nanoparticle volume fraction and particles size in different Reynolds numbers $(900 \leq \mathrm{Re} \leq 2100)$ on convective heat transfer coefficient has been studied. The simulation was conducted for three volume fractions of $1 \%, 3 \%$, and $6 \%$ and particle size of $60 \mathrm{~nm}$, $90 \mathrm{~nm}$, and $150 \mathrm{~nm}$ under laminar flow with a constant thermal flux of $8846.4 \mathrm{w} / \mathrm{m}^{2}$. For validation, the results of this study had compared with the experimental data of Anoop et al. [29] and numerical results of Moraveji et al. [30].

\section{GEOMETRY AND BOUNDARY CONDITIONS}

Figure 1 shows the geometry of the channel [30]. The input side of the channel was considered as the inlet velocity boundary condition and the output side was considered as the outlet pressure boundary condition. A laminar flow regime was considered under boundary condition of constant temperature at the inlet and constant thermal flux was considered on the walls of channel. Also, a no-slip boundary condition was considered on the walls. In this simulation, the flow regime was laminar and the analysis was done for 
the Reynolds numbers of $900 \leq \mathrm{Re} \leq 2100$. The inlet temperature was $300 \mathrm{~K}$ and the constant thermal flux was $8846.4 \mathrm{w} / \mathrm{m}^{2}$ on the walls of channel.

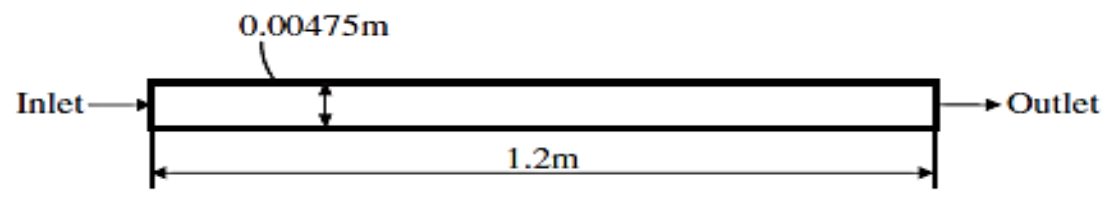

Fig. 1: Schematic geometry of channel [30].

\section{THE BASIC GOVERNING EQUATION ON NANOFLUID FLOW}

Finding the thermophysical properties of nanofluids is one of the most important issues in simulating the flow and heat transfer of nanofluids. Among these properties, it can be noted that study results are significantly dependent on the actual values for the viscosity and thermal conductivity coefficient. The assumption of a single-phase model was considered and the simulation was carried out for the steady state of fluid flow in this channel. Also, the conservation equations are shown respectively below including conservation of mass, conservation of momentum, and conservation of energy.

$$
\begin{aligned}
& \nabla \cdot\left(\rho_{n f} V\right)=0 \\
& \nabla \cdot\left(\rho_{n f} V V\right)=-\nabla P+\nabla \cdot\left(\mu_{n f} \nabla V\right) \\
& \nabla \cdot\left(\rho_{n f} C V T\right)=\nabla \cdot\left(k_{n f} \nabla T\right)
\end{aligned}
$$

\section{EQUATIONS OF NANOFLUID PROPERTIES}

For solving the conservation equations, determination of the thermophysical properties of nanofluids such as density, specific thermal coefficient, and thermal conductivity coefficient is required. In this study, different relations were proposed to determine these characteristics.

$$
\begin{aligned}
& \rho_{n f}=(1-\varphi) \rho_{f}+\varphi \rho_{s} \\
& (\rho \beta)_{n f}=(1-\varphi)(\rho \beta)_{f}+\varphi \beta \rho_{s} \\
& \left(\rho C_{p}\right)_{n f}=(1-\varphi)\left(\rho C_{p}\right)_{f}+\left(\rho C_{p}\right)_{s} \\
& \alpha_{n f}=\frac{k_{n f}}{\left(\rho C_{p}\right)_{n f}}
\end{aligned}
$$

Where $\varphi$ is the volume fraction of particle and the $n f, f$, and $p$ indices represent the nanofluid, base fluid, and particle respectively. Pak et al. [31] experimentally showed that Eq. (4) is a precise definition of the nanofluid density. For solving the equations, the nanofluid thermophysical properties were required. Density, volumetric expansion coefficient, heat capacity, and thermal diffusion coefficient of the nanofluid were calculated from the following relations [32] with the help of fluid and nanoparticle properties. For nanofluid viscosity, various relations were presented in the references where the Brinkman relation [32] is more interesting for researchers than other relations. 


$$
\mu_{n f}=\frac{\mu_{f}}{(1-\varphi)^{2.5}}
$$

Several formulas were presented for nanofluid thermal conductivity coefficient but the formula presented by Patel et al. [33] was used here.

$$
k_{e f f}=k_{f}\left[1+\frac{k_{s} A_{s}}{k_{f} A_{f}}+c k_{s} P e \frac{A_{s}}{k_{f} A_{f}}\right]
$$

In this relation, $k_{s}=36 \mathrm{w} / \mathrm{m} . \mathrm{K}$ is the thermal conductivity coefficient for alumina and $k_{f}=0.6 \mathrm{w} / \mathrm{m} \cdot \mathrm{K}$ is the thermal conductivity coefficient for water. These properties with other required properties for water and alumina nanoparticles are presented in Table 1. $C$ is an experimental constant and equals to 36000 which is reported by Santra et al. [34]. In this relation, the $A_{s} / A_{f}$ ratio was calculated as follows:

$$
\frac{A_{s}}{A_{f}}=\frac{d_{f}}{d_{s}} \frac{\emptyset}{1-\emptyset}
$$

The diameter of the solid nanoparticles was $60 \mathrm{~nm}, 90 \mathrm{~nm}$, and $150 \mathrm{~nm}$. The following formula had used to calculate the molecular diameter [27].

$$
d_{f}=\left[\frac{6 M}{N \pi \rho_{f}}\right]^{1 / 3}
$$

Where in this relation, $M$ is the molecular mass of the base fluid and $N$ is Avogadro number which is equal to $6.022 \times 10^{-23} \mathrm{~mol}^{-1}$.

Also in Eqn. (9), $P e$ was calculated as:

$$
P e=\frac{u_{s} d_{s}}{\alpha_{f}}
$$

In this relation, $u_{s}$ is the Brownian motion velocity of the nanoparticles which is expressed by the following equation:

$$
u_{s}=\frac{2 k_{b} T}{\pi \mu_{f} d_{s}^{2}}
$$

Where $k_{b}$ is Boltzmann constant, $k_{b}=1.3807 \times 10^{-23} \mathrm{~J} / \mathrm{K}$. The following equations were used to calculate the heat transfer coefficient and the Nusselt number.

$$
\begin{aligned}
& N u=\frac{h(x) D}{k} \\
& h(x)=\frac{q^{\prime \prime}}{\left(T_{w}(x)-T_{f}(x)\right.}
\end{aligned}
$$

Where $q$ ", $D, k, T_{w}$ and $T_{f}$ are the heat flux, diameter, fluid thermal conductivity, wall temperature, and film temperature along the wall in an axial position. The physical properties of alumina, water-based fluid and fuel-oil-based fluids such as density, specific heat, thermal conductivity coefficient, and viscosity are given in Table 1. 


\section{NUMERICAL METHOD}

In this study, the second-order upwind method was used because it provides more accurate results. The coupling between velocity and pressure terms was handled using the Semi-Implicit Method for Pressure Linked Equations (SIMPLE) algorithm. The assumption of a single-phase model was considered and simulation was done for the steady-state flow of fluid in the channel. The general form of conservation equations is similar to ordinary fluids in the single-phase method but for the density, thermal conductivity, viscosity and specific heat, the apparent properties of the nanofluid were used. In this method, the slip between the base fluid and the nanoparticles was ignored and the effect of the presence of particles on the apparent properties was seen.

Table 1: The physical properties of alumina, fuel-oil-based fluid and water-based fluid

\begin{tabular}{ccccc}
\hline Properties & $\boldsymbol{\rho}\left[\mathbf{K g} / \mathbf{m}^{3}\right]$ & $\mathbf{C}_{\mathbf{p}}[\mathbf{J} / \mathbf{k g} . \mathbf{K}]$ & $\mathbf{K}[\mathbf{W} / \mathbf{m} . \mathbf{K}]$ & $\boldsymbol{\mu}[\mathbf{K g} / \mathbf{m} . \mathbf{s}]$ \\
\hline Alumina & 3600 & 765 & 36 & - \\
Fuel-oil & 960 & 1880 & 0.12 & 0.048 \\
Water & 998.2 & 4182 & 0.6 & 0.001003 \\
\hline
\end{tabular}

\section{GRID INDEPENDENCE}

In the present study, four different grids were generated for the channel in order to investigate the grid independence and the results for the four grids were compared. The numbers of nodes were 7590, 10263, 13728, and 25309 respectively, and these were used to calculate the heat transfer coefficient in terms of the Reynolds number. Then, for comparing the results with other grids, it was observed that there was little difference between the finest grid and the grid with 13728 nodes. Therefore, in order to save calculation time, the grid with 13728 nodes was used to obtain the results. Figure 2 shows the details of grid independence.

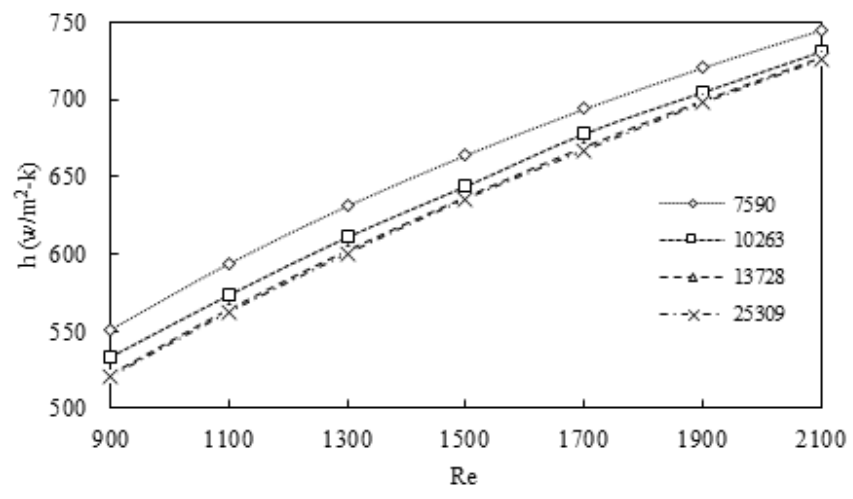

Fig. 2: Grid independence study.

\section{VALIDATION}

In general, experimental study of nanofluids is a very extensive research and there are multiple variables, the most important among them are thermal conductivity and viscosity. Different researches had reported different values for these variables, as well as their dependence on each other or on other variables according to different experimental conditions. Various relations, or mathematical models, were presented in this field that 
indicated the same variety of results in the research. The experimental data of Anoop et al. [29] and numerical results of Moraveji et al. [30] were considered for validation in the present study which the changes of convective heat transfer coefficient were investigated based on the Reynolds number (Fig. 3). The geometry of the study of Moraveji et al. [30] is the same as the experimental study of Anoop et al. [29]. The results showed that the present study was in good agreement with the experimental data of Anoop et al. [29] and numerical results of Moraveji et al. [30].

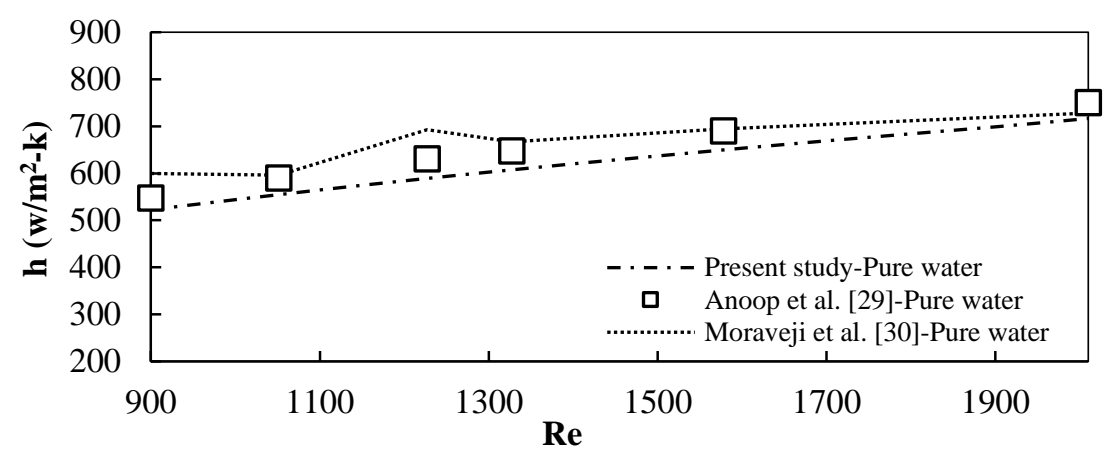

Fig. 3: Comparing the changes of convective heat transfer coefficient based on the Reynolds number with the experimental data of Anoop et al. [29] and numerical results of Moraveji et al. [30].

\section{RESULTS AND DISCUSSION}

\subsection{The changes in the thermal conductivity ratio based on the percentages of the volume fraction of nanoparticles}

Figure 4 shows the increase in thermal conductivity rate based on the volume fraction percentages of nanoparticles for water-alumina and fuel-oil-alumina nanofluids as calculated from the formula provided by Patel et al. [33]. As can be seen, the thermal conductivity rate is greater than 1 for all nanofluids and it increases by increasing the volume fraction of nanoparticles [35]. The highest rate of increase is for the fuel-oilalumina nanofluid with a volume fraction of $6 \%$ and a particle size of $60 \mathrm{~nm}$. It should be noted that the effective thermal conductivity of nanofluids depends on the thermal conductivity of solid particles and the base fluid, the volume fraction of the particle, particle shape, thickness, and thermal conductivity of the nano layer [36]. Also, thermal conductivity depends on the particle size, nanoparticle density, and the combination of characteristics of the base fluid and the nanoparticles [37, 38].

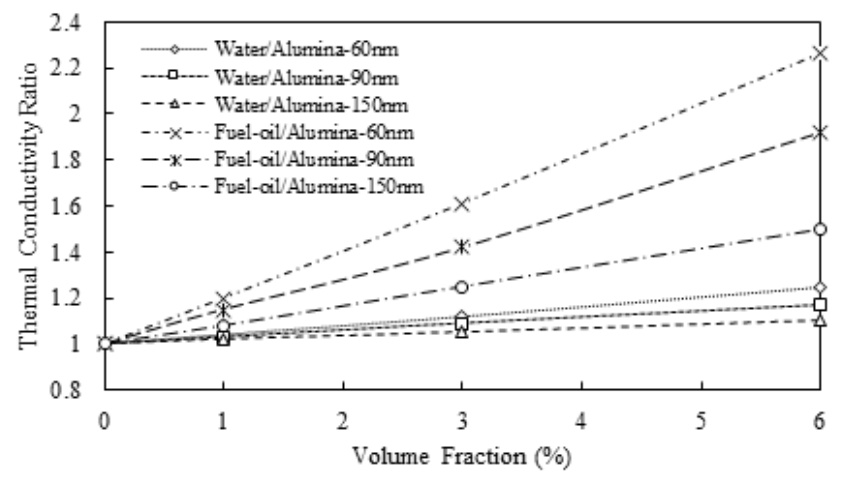

Fig. 4: The changes of thermal conductivity rate based on the percentages of the volume fraction of nanoparticles. 


\subsection{The Changes in the Nusselt Number Based on the Percentages of the Volume Fraction of Nanoparticles}

Figures 5, 6 and 7 show the changes in the Nusselt number based on the Reynolds number for the nanofluid with particles of $60 \mathrm{~nm}, 90 \mathrm{~nm}$, and $150 \mathrm{~nm}$ in volume fractions of $1 \%, 3 \%, 6 \%$, and base fluid (pure water). As can be seen, the Nusselt number increases with the increasing Reynolds number and increasing volume fraction of nanoparticles so that this increase is more remarkable at high Reynolds numbers. This increase is very low for a volume fraction of $1 \%$ but a significant increase can be observed by increasing the nanoparticle density to $6 \%$. The Nusselt number increases about $16 \%$ in a volume fraction of $6 \%$ and at Reynolds number of 2100 for nanofluid with particles of $60 \mathrm{~nm}$ compared to base fluid, for a nanofluid with particles of $90 \mathrm{~nm}$, about $12 \%$ compared to base fluid and for nanofluid with particles of $150 \mathrm{~nm}$, about $9 \%$ compared to base fluid.

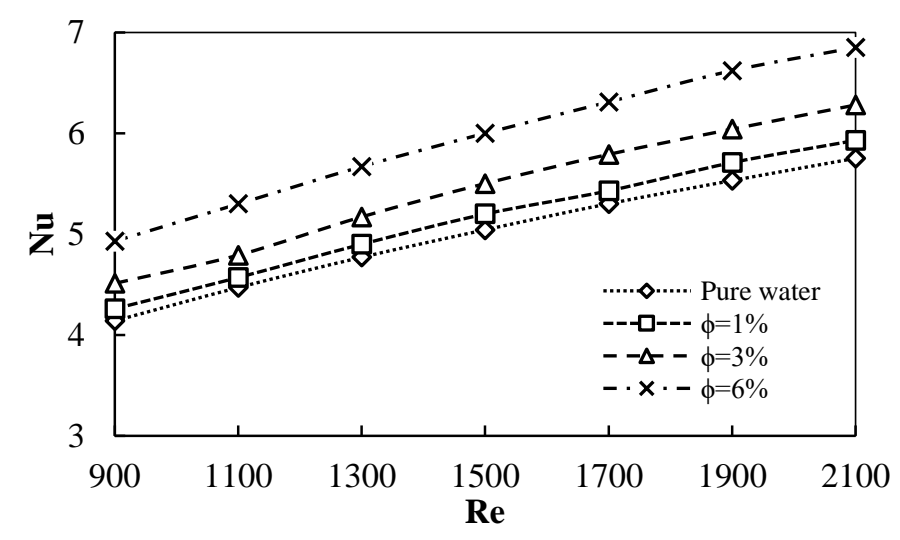

Fig. 5: The changes in the Nusselt number of water-based nanofluid with particles of $60 \mathrm{~nm}$ based on the Reynolds number.

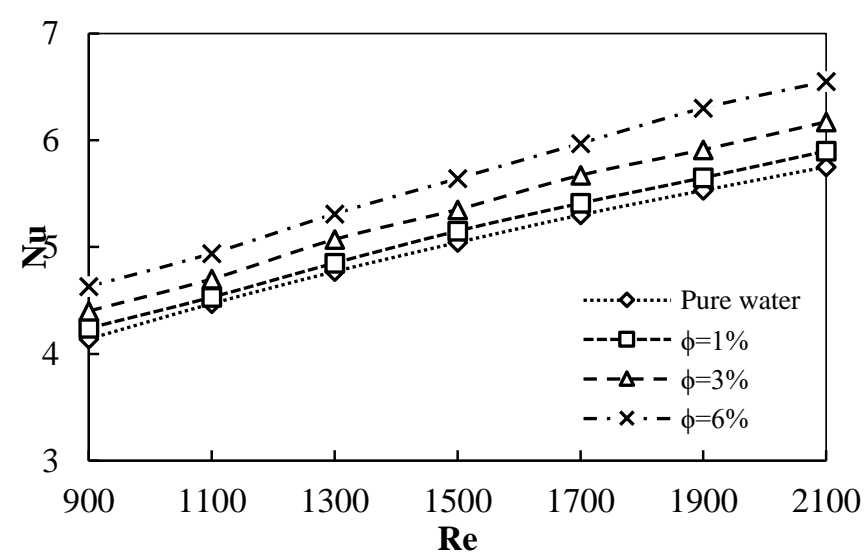

Fig. 6: The changes in the Nusselt number of water-based nanofluid with particles of $90 \mathrm{~nm}$ based on the Reynolds number.

Figures 8, 9 and 10 show the changes in the Nusselt number based on the Reynolds number for a nanofluid with particles of $60 \mathrm{~nm}, 90 \mathrm{~nm}$, and $150 \mathrm{~nm}$ in volume fractions of $1 \%, 3 \%, 6 \%$, and base fluid (fuel-oil). In these figures, the Nusselt number increases significantly with increasing volume fraction of nanoparticles but it increases with a slight slope with increase in the Reynolds number. This increase is very low for all particles, but a significant increase can be observed by increasing the nanoparticles density to $6 \%$. In this way, the Nusselt number increases about $56 \%$ in a volume fraction of $6 \%$ and at a 


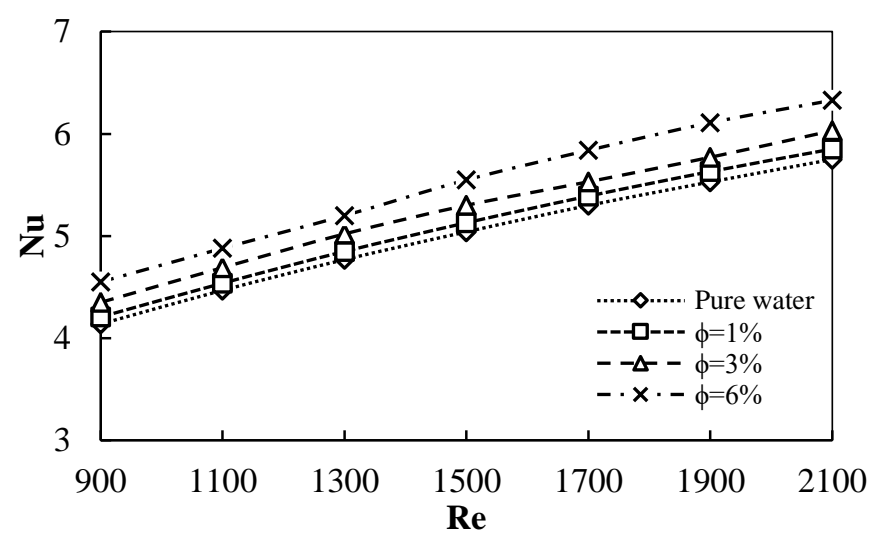

Fig. 7: The changes in the Nusselt number of water-based nanofluid with particles of $150 \mathrm{~nm}$ based on the Reynolds number.

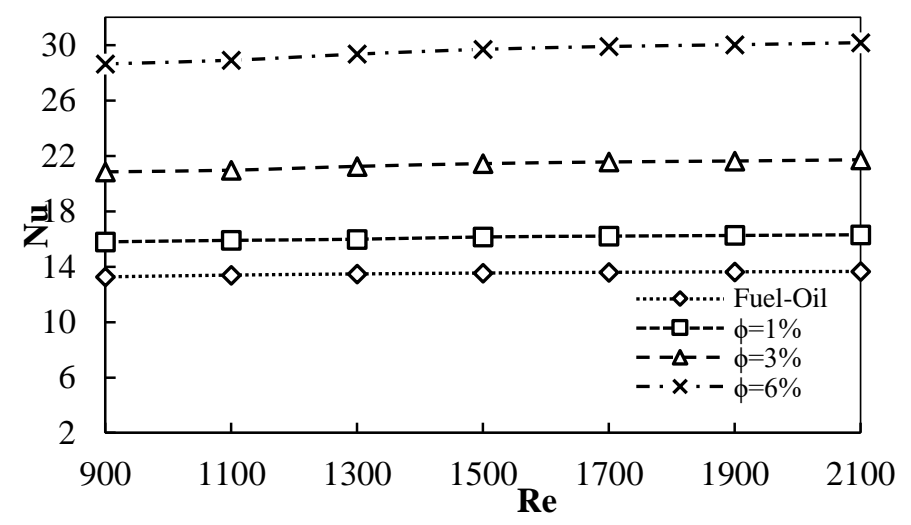

Fig. 8: The changes in the Nusselt number of fuel-oil-based nanofluid with particles of $60 \mathrm{~nm}$ based on the Reynolds number.

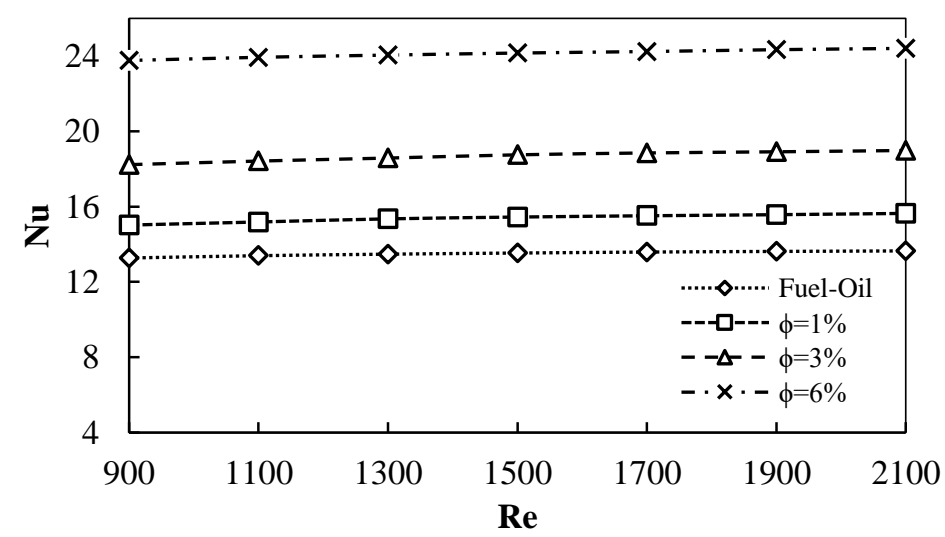

Fig. 9: The changes in the Nusselt number of fuel-oil-based nanofluid with particles of $90 \mathrm{~nm}$ based on the Reynolds number.

Reynolds number of 2100 for a nanofluid with particles of $60 \mathrm{~nm}$ compared to the base fluid, for a nanofluid with $90 \mathrm{~nm}$ particles, about $44 \%$ compared to base fluid, and for a nanofluid with particles of $150 \mathrm{~nm}$ about $33 \%$ compared to base fluid. 


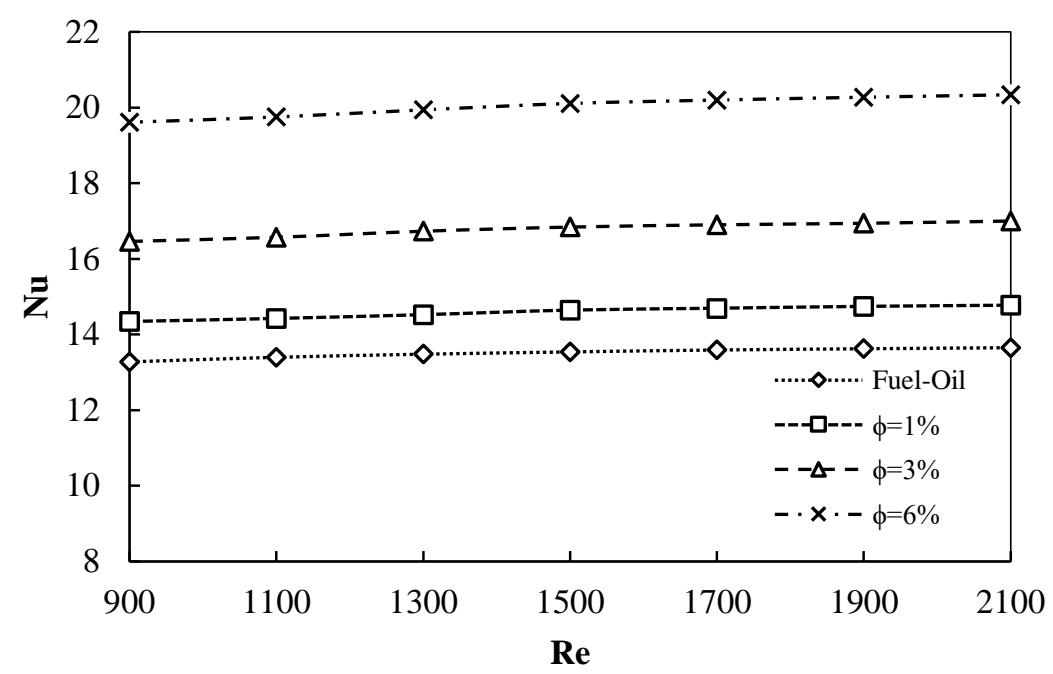

Fig. 10: The changes in the Nusselt number of fuel-oil-based nanofluid with particles of $150 \mathrm{~nm}$ based on the Reynolds number.

\subsection{Effect of Volume Fraction of Nanoparticles on Convective Heat Transfer Coefficient}

Figures 11, 12 and 13 show the changes in the convective heat transfer coefficient based on the Reynolds number for nanofluids with particles of $60 \mathrm{~nm}, 90 \mathrm{~nm}$, and $150 \mathrm{~nm}$ of alumina with volume fractions of $1 \%, 3 \%, 6 \%$, and base fluid (pure water). By increasing the nanoparticle density with particles of $60 \mathrm{~nm}, 90 \mathrm{~nm}$, and $150 \mathrm{~nm}$ from $1 \%$ to $6 \%$ at the Reynolds number of 2100 , the convective heat transfer coefficient has its highest rate of increase. By comparing the figures, it can be found that convective heat transfer coefficient increases with the reduction of particle size. Experiments showed that convective heat transfer coefficient increased by adding nanoparticles to the base fluid. The reasons for this increase are related to the increase in the turbulence of the vortices, the reduction of the boundary layer thickness, the inverse dispersion of suspended nanoparticles, the significant increase in the thermal conductivity and the thermal capacity of the fluid. [39]. As can be seen, the convective heat transfer coefficient increases significantly by increasing the Reynolds number. Regardless of the significant increase in convective heat transfer coefficient of a nanofluid with increasing Reynolds number, it is observed that this coefficient increases simultaneously with a decrease in particle size for a constant Reynolds number. The distance between the curves in Fig. 13 is greater than Fig. 11 and Fig. 12. In the other words, the effect of particle size on the convective heat transfer coefficient of a nanofluid is greater at higher Reynolds numbers in the present study. Therefore, reducing particle size has a better effect on increasing the convective heat transfer coefficient of nanofluids at higher Reynolds numbers. Another point that can be derived from the figures is that by increasing the Reynolds number and for constant sizes of nanoparticles, higher nanoparticle density is needed to achieve higher heat transfer coefficients but at lower Reynolds numbers, the use of lower nanoparticle density also has a good effect on increasing heat transfer coefficient. 


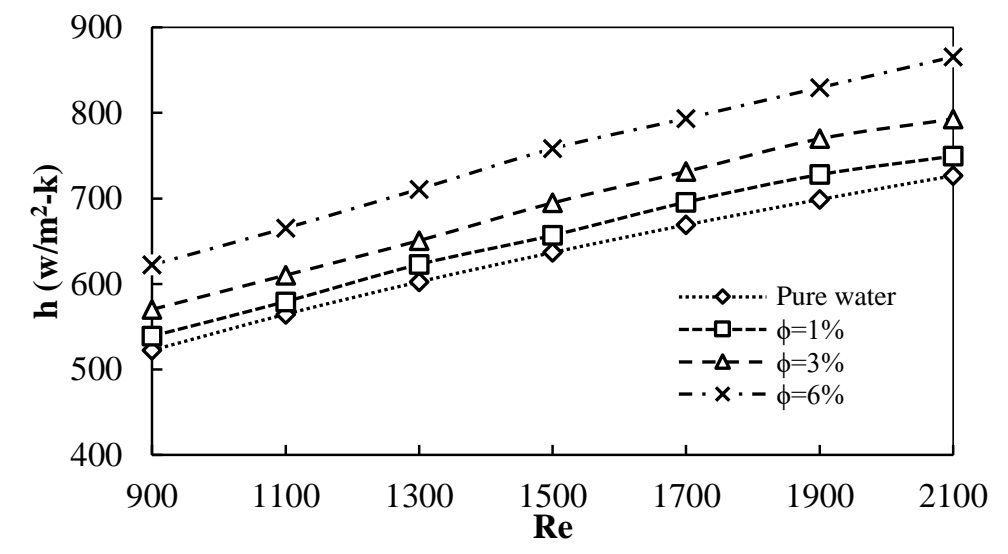

Fig. 11: The effect of particle volume fraction and Reynolds number on convective heat transfer coefficient for particles of $60 \mathrm{~nm}$.

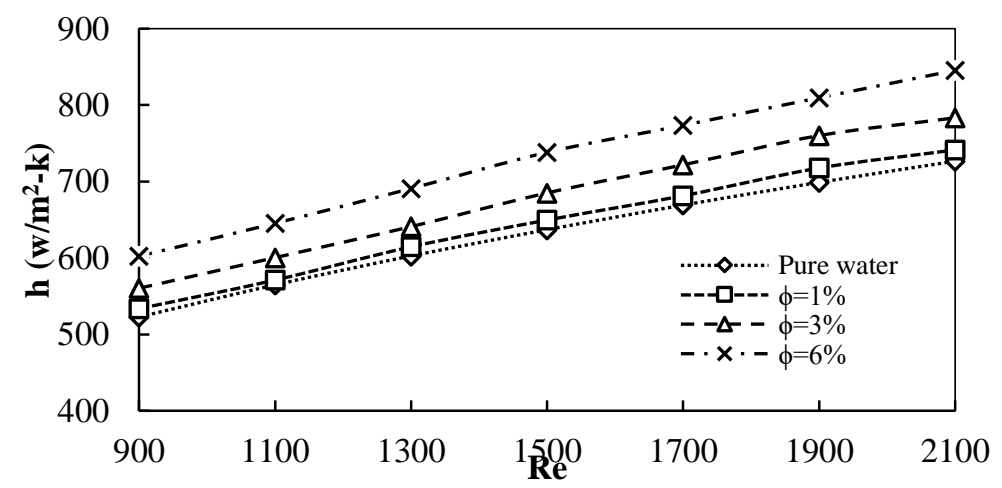

Fig. 12: The effect of particle volume fraction and Reynolds number on convective heat transfer coefficient for particles of $90 \mathrm{~nm}$.

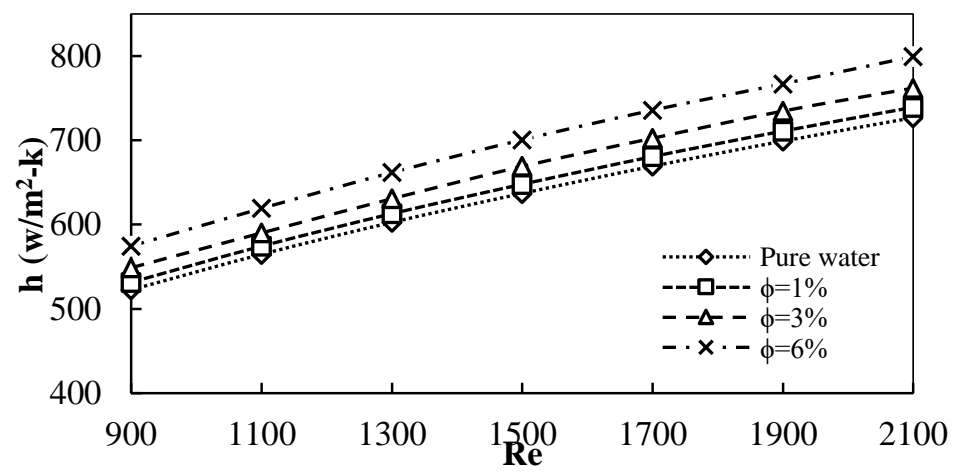

Fig. 13: The effect of particle volume fraction and Reynolds number on convective heat transfer coefficient for particles of $150 \mathrm{~nm}$.

Figure 14, 15 and 16 show the changes of convective heat transfer coefficient based on Reynolds number for nanofluid with particles of $60 \mathrm{~nm}, 90 \mathrm{~nm}$ and $150 \mathrm{~nm}$ of alumina with volume fractions of $1 \%, 3 \%, 6 \%$, and base fluid (fuel-oil). It can be seen that with the increase in the Reynolds number, the convective heat transfer coefficient is increased with a slight slope. For example, the convective heat transfer coefficient is 723.23 at $\varphi=6 \%$ and $\operatorname{Re}=900$ and it is 762.78 at $\varphi=6 \%$, and $R e=2100$ for nanoparticles of $60 \mathrm{~nm}$, which is increased by about $5 \%$. The convective heat transfer coefficient increases with the increase of volume fraction of nanoparticles [34]. Therefore, the increase in the convective heat 
transfer coefficient is observed to be about $55 \%$ at $\varphi=6 \%$ and $\mathrm{Re}=2100$. The remarkable point is that at the same Reynolds number and volume fraction, the amount of convective transfer heat transfer coefficient is decreased with the increase of the size of the nanoparticles.

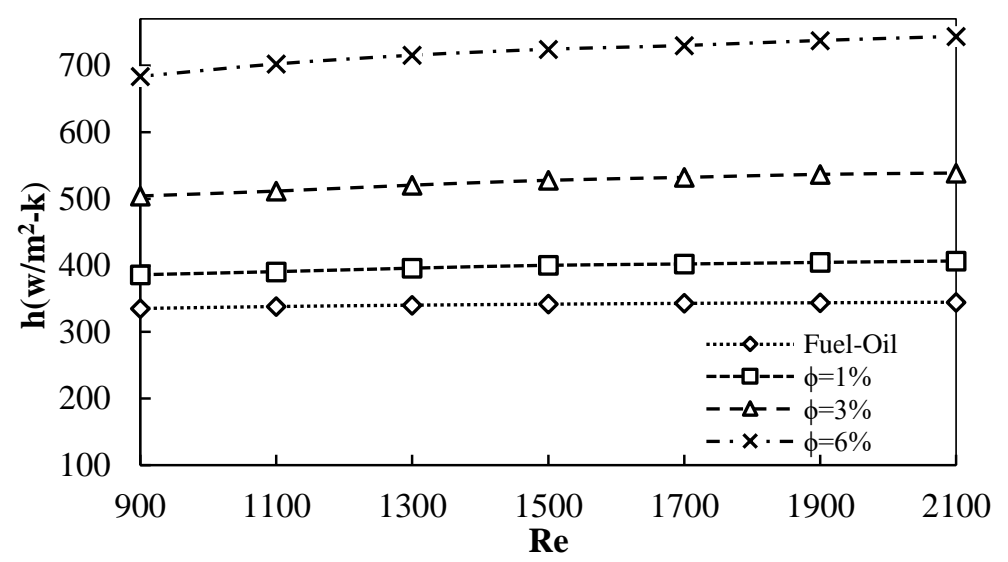

Fig. 14: The effect of particle volume fraction and Reynolds number on convective heat transfer coefficient for particles of $60 \mathrm{~nm}$.

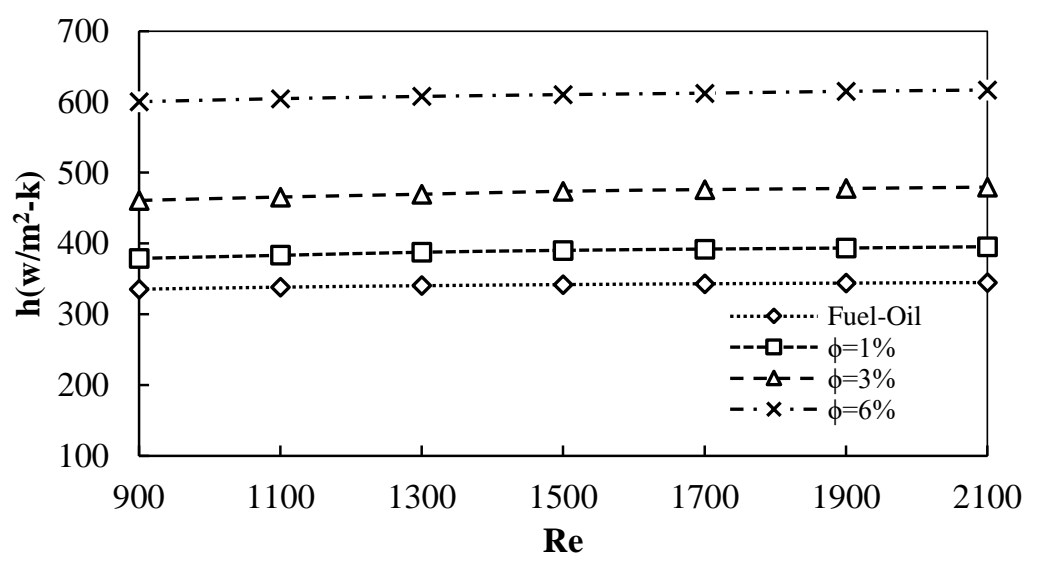

Fig. 15: The effect of particle volume fraction and Reynolds number on convective heat transfer coefficient for particles of $90 \mathrm{~nm}$.

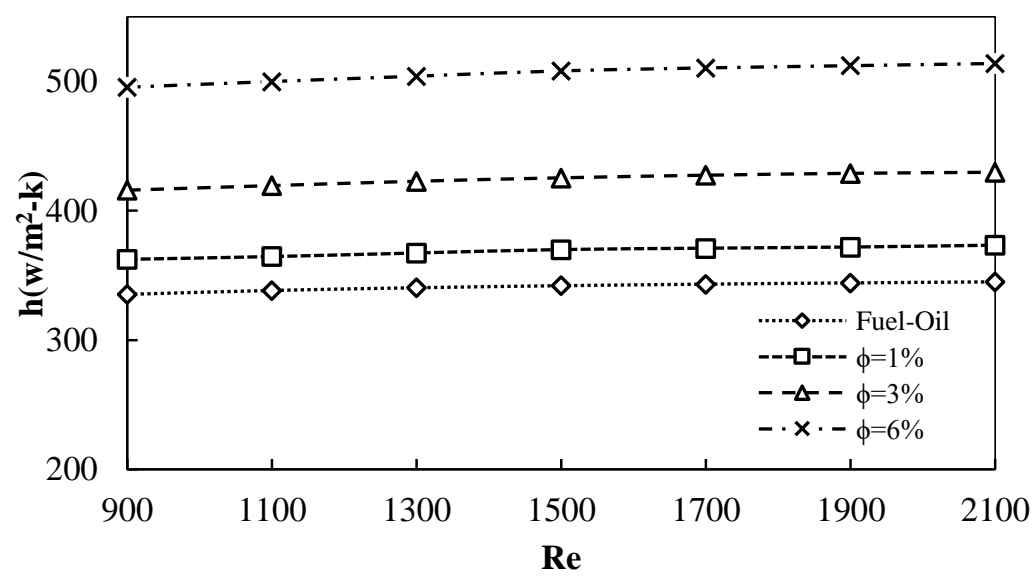

Fig. 16: The effect of particle volume fraction and Reynolds number on convective heat transfer coefficient for particles of $150 \mathrm{~nm}$. 


\subsection{Effect of Nanoparticle Size on Nusselt Number}

Figure 17 shows the changes in the Nusselt number for a nanofluid with particles of $60 \mathrm{~nm}, 90 \mathrm{~nm}$, and $150 \mathrm{~nm}$ with volume fraction of $1 \%$ and water-based fluid at Reynolds numbers from 900 to 2100 . It is concluded from the figures that smaller nanoparticles have a larger Nusselt number than larger nanoparticles. So that it is increased about $20 \%$ at $\varphi=$ $1 \%$ and $\mathrm{Re}=2100$ for nanoparticles of $60 \mathrm{~nm}$ but it is increased about $15 \%$ for nanoparticles of $90 \mathrm{~nm}$ at $\varphi=1 \%$ and $\mathrm{Re}=2100$ and for nanoparticles of $150 \mathrm{~nm}$ at $\varphi=1 \%$ and $\mathrm{Re}=2100$, it is increased about $10 \%$ higher than the base fluid. Also, the increase of Reynolds number causes an increase in the Nusselt number and the maximum amount of increase in the Nusselt number is for nanoparticles of $60 \mathrm{~nm}$ is about $29 \%$.

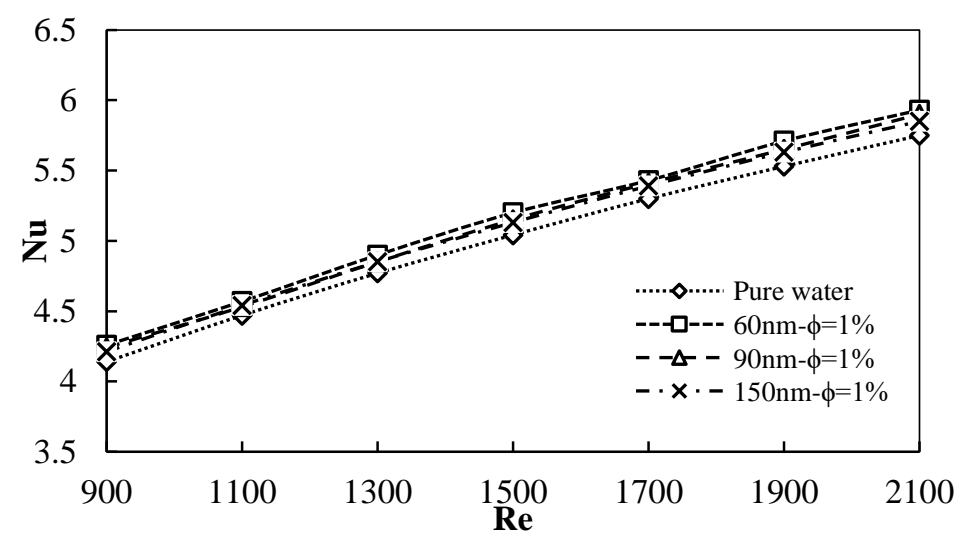

Fig. 17: Comparing the changes in the Nusselt number for a water-based nanofluid with particles of $60 \mathrm{~nm}, 90 \mathrm{~nm}$, and $150 \mathrm{~nm}$ with a volume fraction of $1 \%$ and water-based fluid.

Figure 18 shows the changes of Nusselt number for a nanofluid with particles of 60 $\mathrm{nm}, 90 \mathrm{~nm}$, and $150 \mathrm{~nm}$ with volume fraction of $1 \%$ and fuel-oil-based fluid at Reynolds numbers from 900 to 2100. As the Reynolds number increases, the Nusselt number increases with a slight slope. It is concluded from the figures that smaller nanoparticles have a larger Nusselt numbers than larger nanoparticles. It is increased about $16 \%$ at $\varphi=$ $1 \%$ and $\mathrm{Re}=2100$ for nanoparticles of $60 \mathrm{~nm}$ but it is increased about $13 \%$ for nanoparticles of $90 \mathrm{~nm}$ at $\varphi=1 \%$ and $\mathrm{Re}=2100$ and for nanoparticles of $150 \mathrm{~nm}$ at $\varphi=1 \%$ and $\operatorname{Re}=2100$, it is increased about $7 \%$ higher than the base fluid.

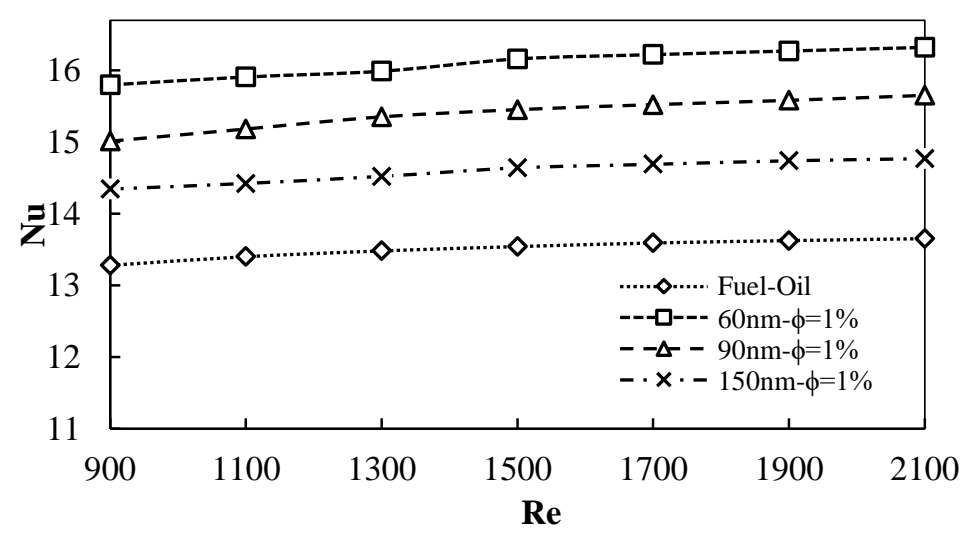

Fig. 18: Comparing the changes of Nusselt number for fuel-oil-based nanofluid with particles of $60 \mathrm{~nm}, 90 \mathrm{~nm}$, and $150 \mathrm{~nm}$ with a volume fraction of $1 \%$ and fuel-oil based fluid. 


\subsection{Effect of Nanoparticle Size on Convective Heat Transfer Coefficient}

Figure 19 shows the changes of convective heat transfer coefficient for nanofluids with particles of $60 \mathrm{~nm}, 90 \mathrm{~nm}$, and $150 \mathrm{~nm}$ with a volume fraction of $1 \%$ and water base fluid at Reynolds numbers from 900 to 2100. It is quite obvious that nanofluids have higher convective heat transfer coefficient than the base fluid [29]. By increasing the Reynolds number, the convective heat transfer coefficient increases with a large slope. Also, smaller nanoparticles have larger Nusselt numbers than larger nanoparticles. For example, it increases about $4 \%$ at $\varphi=1 \%$ and $\mathrm{Re}=2100$ for nanoparticles of $60 \mathrm{~nm}$, for nanoparticles of $90 \mathrm{~nm}$ at $\varphi=1 \%$ and $\mathrm{Re}=2100$ it increases about $3 \%$ and for nanoparticles of $150 \mathrm{~nm}$ at $\varphi=1 \%$ and $\mathrm{Re}=2100$ it increases about $2 \%$ than base fluid. The effect of the Reynolds number on increasing the convective heat transfer coefficient is greater than the effect of nanoparticle size, so that the maximum amount of increase in convective heat transfer coefficient for nanoparticles of $60 \mathrm{~nm}$ and at a Reynolds number of 2100 is about $28 \%$.

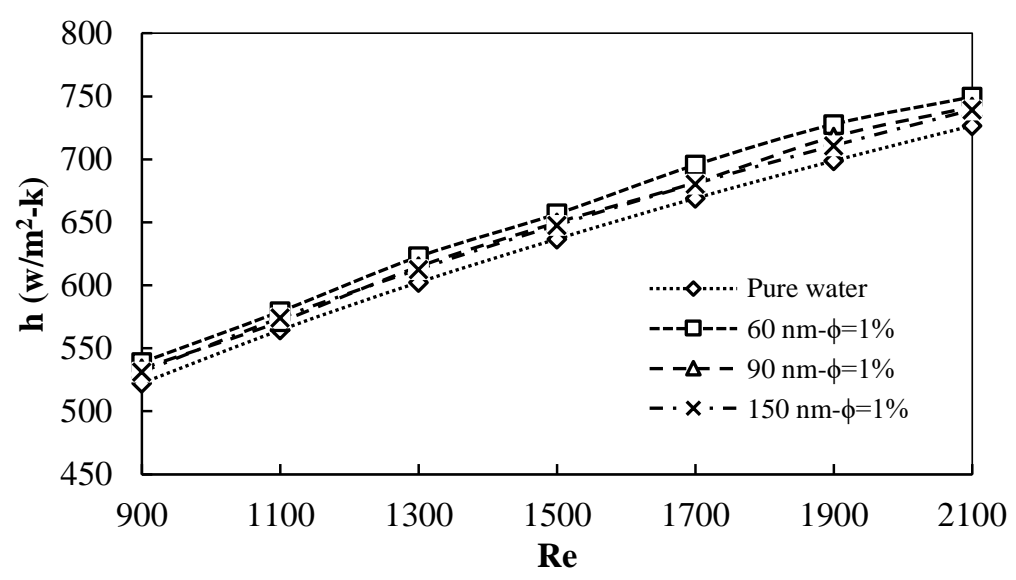

Fig. 19: Comparing the changes of convective heat transfer coefficient for water-based nanofluid with particles of $60 \mathrm{~nm}, 90 \mathrm{~nm}$, and $150 \mathrm{~nm}$ with a volume fraction of $1 \%$ and water-based fluid.

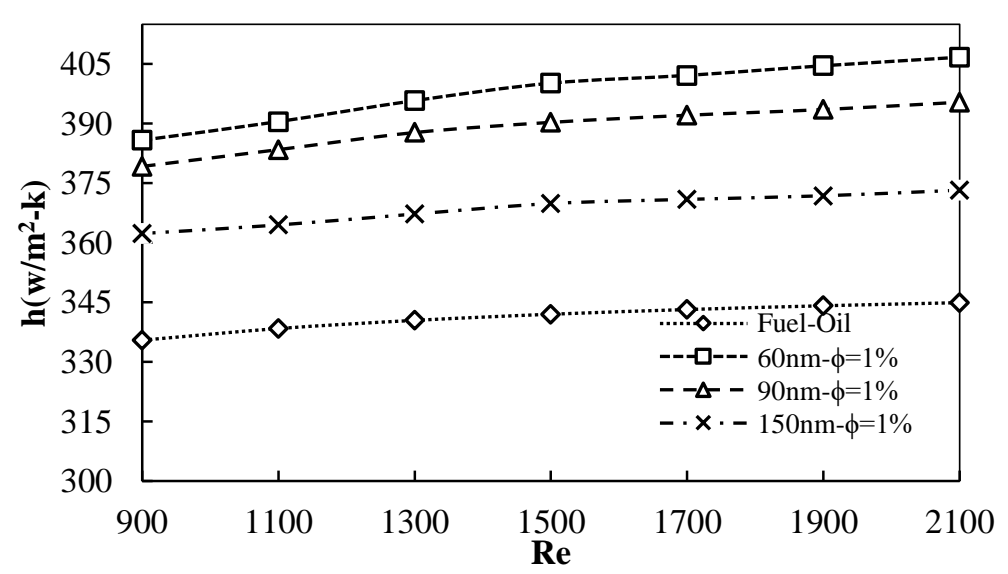

Fig. 20: Comparing the changes of convective heat transfer coefficient for fuel-oil base nanofluid with particles of $60 \mathrm{~nm}, 90 \mathrm{~nm}$, and $150 \mathrm{~nm}$ with a volume fraction of $1 \%$ and fuel-oil based fluid.

Figure 20 shows the changes of convective heat transfer coefficient for nanofluids with particles of $60 \mathrm{~nm}, 90 \mathrm{~nm}$ and $150 \mathrm{~nm}$ with volume fractions of $1 \%$ and fuel-oil based 
fluids at Reynolds numbers from 900 to 2100. By increasing the Reynolds number, the convective heat transfer coefficient is increased and the slope of the increase in nanoparticles with smaller size is greater than in other cases. For example, it increases about $15 \%$ at $\varphi=1 \%$ and $\mathrm{Re}=2100$ for nanoparticles of $60 \mathrm{~nm}$ but for nanoparticles of 90 $\mathrm{nm}$ at $\varphi=1 \%$ and $\mathrm{Re}=2100$ it increases about $12 \%$ and for nanoparticles of $150 \mathrm{~nm}$ at $\varphi=$ $1 \%$ and $\mathrm{Re}=2100$ it increases about $7 \%$ compared to base fluid.

\subsection{Changes in the Convective Heat Transfer Coefficient Based on Axial Position}

Figure 21 shows the changes of Nusselt number for a nanofluid with particles of 60 $\mathrm{nm}, 90 \mathrm{~nm}$, and $150 \mathrm{~nm}$ with volume fraction of $1 \%$ and water base fluid based on the axial position. It is concluded from the figures that by increasing the axial position, convective heat transfer coefficient decreases so that the value of this coefficient in the inlet is more than the other parts [40], which is similar to the results of Wen and Ding [21] who studied nanofluid heat transfer in micro channels. This coefficient decreases significantly at the inlet of the channel and it decreases with a very small slope after $50 \%$ of the length of the channel. It is also observed that the nanofluid with smaller particles has a higher convective heat transfer coefficient than larger particles at the same axial position for a constant volume fraction. For example, convective heat transfer coefficient has decreased about $76 \%$ from the inlet to the outlet of the channel for particles of $60 \mathrm{~nm}$.

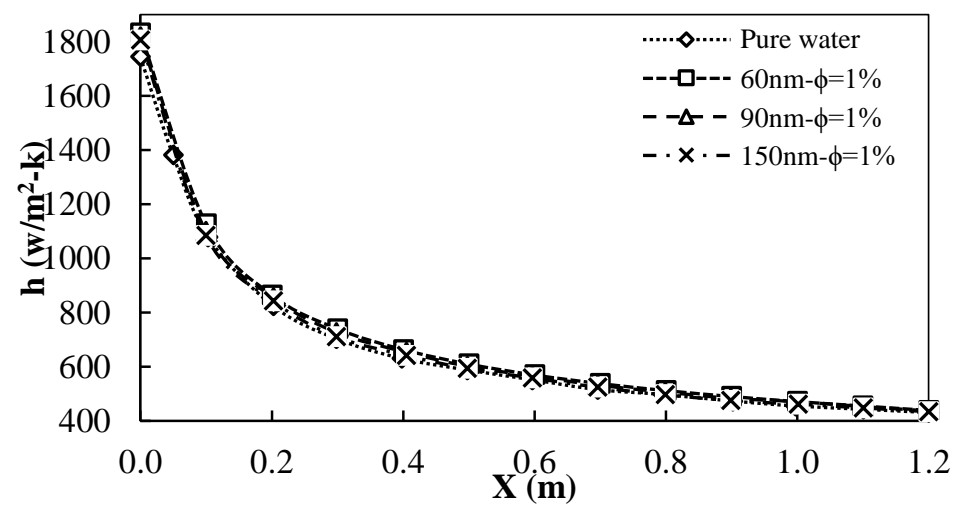

Fig. 21: Comparing the changes of convective heat transfer coefficient for water-based nanofluid with particles of $60 \mathrm{~nm}, 90 \mathrm{~nm}$, and $150 \mathrm{~nm}$ with a volume fraction of $1 \%$ and water based fluid based on axial position.

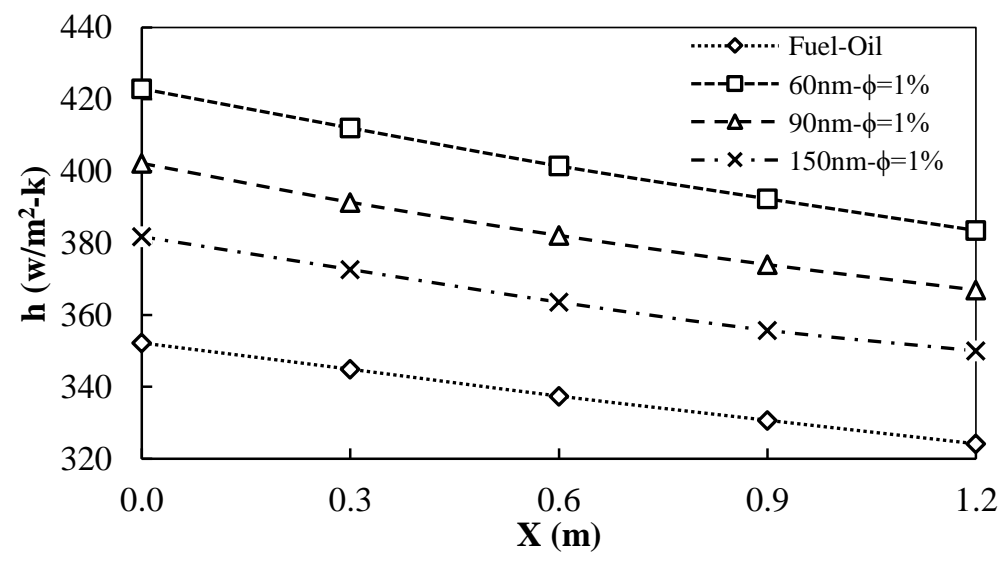

Fig. 22: Comparing the changes of convective heat transfer coefficient for

fuel-oil-based nanofluid with particles of $60 \mathrm{~nm}, 90 \mathrm{~nm}$, and $150 \mathrm{~nm}$ with a volume fraction of $1 \%$ and fuel-oil based fluid based on axial position. 
Figure 22 shows the changes of Nusselt number for a nanofluid with particles of 60 $\mathrm{nm}, 90 \mathrm{~nm}$, and $150 \mathrm{~nm}$ with volume fraction of $1 \%$ and fuel-oil base fluid based on the axial position. Similar to water-based fluid, the value of the convective heat transfer coefficient in the inlet is more than the other parts [31]. Also, this coefficient decreases by increasing the length of the channel but its reduction is not similar to the water-based fluid and it decreases with almost the same slope along the length of the channel. As it is clear, the amount of convective heat transfer is greater in nanoparticles with smaller sizes.

\subsection{Comparison of the Changes of Temperature at the End of the Channel}

Figures 23 and 24 show the changes in temperature at the end of the channel for water-alumina and fuel oil-alumina nanofluids at Reynolds numbers of 900 and 2100 for a volume fraction of $6 \%$ and nanoparticles of $60 \mathrm{~nm}$. Nanofluids have heated through the channel wall, and their temperature is increased along the length of channel [30] so that a higher temperature is observed near the channel wall as compared to the other parts of the channel. Little changes are observed at Reynolds numbers of 900 and 2100 for fuel oilalumina nanofluid. Also, the maximum temperature of nanofluid at a Reynolds number of 900 is higher than at a Reynolds number of 2100 , because the convective heat transfer coefficient at higher Reynolds numbers is higher than at low Reynolds numbers [30].

(a) $\operatorname{Re}=900$

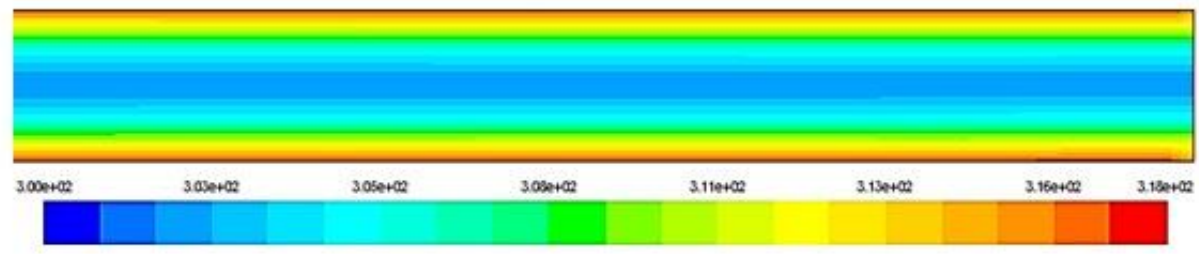

(b) $\operatorname{Re}=2100$

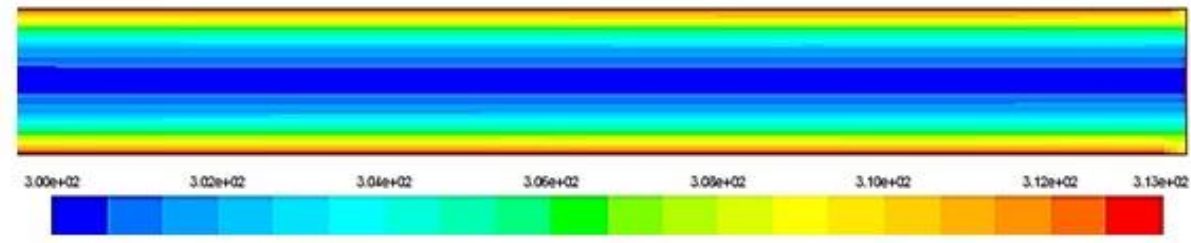

Fig. 23: The changes of temperature at the end of the channel for water-alumina nanofluid (60 $\mathrm{nm}-6 \%)$.

(a) $\mathrm{R}=900$

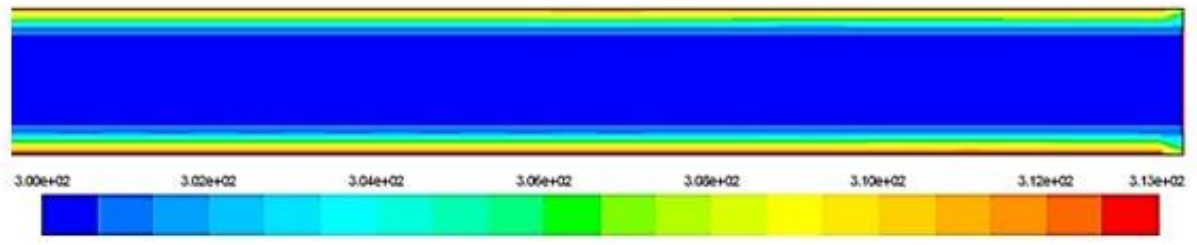

(b) $\operatorname{Re}=2100$

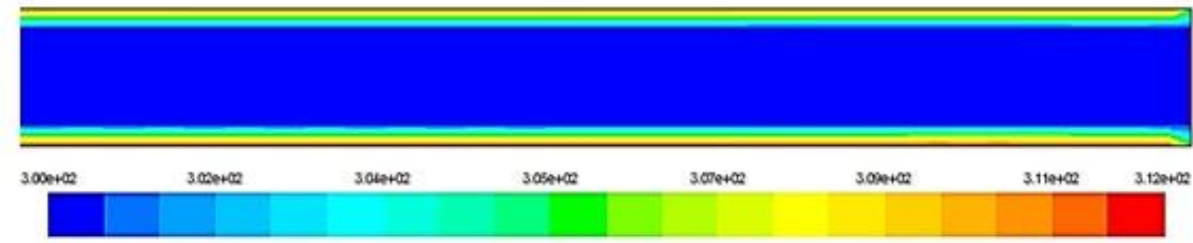

Fig. 24: The changes of temperature at the end of the channel for fuel oil-alumina $(60 \mathrm{~nm}-6 \%)$. 


\section{CONCLUSION}

In this study, convective heat transfer of fuel oil-alumina and water-alumina nanofluids flow in a channel in a laminar flow was conducted using Fluent. The effects of nanoparticle volume fraction, nanoparticle size, axial position and the Reynolds number on the convective heat transfer coefficient and the Nusselt number were studied. The simulation was conducted for three volume fractions of $1 \%, 3 \%$ and $6 \%$ and particle sizes of $60 \mathrm{~nm}, 90 \mathrm{~nm}$, and $150 \mathrm{~nm}$ in laminar flow with a constant thermal flux of $8846.4 \mathrm{w} /$ $\mathrm{m}^{2}$ where the following results were obtained from this study:

- Increasing of the nanoparticle volume fraction causes an increase in the convective heat transfer coefficient and the Nusselt number of the nanofluid.

- The Reynolds number has a significant effect on convective heat transfer coefficient of water-alumina nanofluid and increase of the Reynolds number increases this coefficient. By increasing the Reynolds number, convective heat transfer coefficient of fuel oil-alumina nanofluid slightly increases.

- By increasing the axial position, the amount of convective heat transfer coefficient in both nanofluids decreases. It is also observed that in a constant volume fraction, a nanofluid with smaller particles has a higher convective heat transfer coefficient than larger particles in the same axial position.

- According to the axial position, the amount of convective heat transfer coefficient at the inlet of the channel is more than in the other parts of the channel for wateralumina nanofluid and by increasing the axial position, this coefficient decreases with a large slope. The axial position of this coefficient is reduced with a large slope which the convective heat transfer coefficient decreases with almost the same slope along the channel for the fuel oil-alumina nanofluid.

- The rate of thermal conductivity for all nanofluids is greater than 1 and this amount increases by increasing the volume fraction of nanoparticles so that the highest increase rate is for a fuel oil-alumina nanofluid in a volume fraction of $6 \%$ and a particle size of $60 \mathrm{~nm}$.

- The effect of the Reynolds number on increasing the convective heat transfer coefficient for water-alumina nanofluid is more than the effect of nanoparticle size so that in a volume fraction of $1 \%$, the highest increase rate for convective heat transfer coefficient is about $28 \%$ for nanoparticles of $60 \mathrm{~nm}$ and at a Reynolds number of 2100. But for fuel oil-alumina nanofluid, the effect of increasing of the size of nanoparticles is greater than the effect of the increase in the Reynolds number.

The results of this study can be used in refineries and petrochemical industries where the fuel-oil fluid flows in channels.

\section{REFERENCES}

[1] Mirmasoumi S, Behzadmehr A. (2008) Numerical study of laminar mixed convection of a nanofluid in a horizontal tube using two-phase mixture model. Applied Thermal Engineering, 28(7):717-727.

[2] Maïga SB, Nguyen CT, Galanis N, Roy G. (2004) Heat transfer behaviors of nanofluids in a uniformly heated tube. Superlattices and Microstructures, 35(3):543-557.

[3] Prasher R, Song D, Wang J, Phelan P. (2006) Measurements of nanofluid viscosity and its implications for thermal applications. Applied Physics Letters, 89(13):133-140. 
[4] Bianco V, Manca O, Nardini S. (2011) Numerical investigation on nanofluids turbulent convection heat transfer inside a circular tube. International Journal of Thermal Sciences, 50(3):341-349.

[5] Bianco V, Manca O, Nardini S. (2010) Numerical simulation of water/A12O3 nanofluid turbulent convection. Advances in Mechanical Engineering, Article ID976254:1-10.

[6] Bianco V, Nardini S, Manca O. (2011) Enhancement of heat transfer and entropy generation analysis of nanofluids turbulent convection flow in square section tubes. Nanoscale research letters, 6(1):252-259.

[7] Corcione M, Cianfrini M, Quintino A. (2012) Heat transfer of nanofluids in turbulent pipe flow. International Journal of Thermal Sciences, 56(3):58-69.

[8] Rahimi-Esbo M, Ranjbar A. A, Ramiar A, Rahgoshay M, Arya A. (2012) Numerical study of the turbulent forced convection jet flow of nanofluid in a converging duct. Numerical Heat Transfer, Part A: Applications, 62(1):60-79.

[9] Ghaffari O, Behzadmehr A, Ajam H. (2010) Turbulent mixed convection of a nanofluid in a horizontal curved tube using a two-phase approach. International Communications in Heat and Mass Transfer, 37(10):1551-1558.

[10] Massoudi M, Phuoc T X. (2012) Remarks on constitutive modeling of nanofluids. Advances in Mechanical Engineering, 4(1):90-105.

[11] Yimin X, Li Q. (2000) Heat transfer enhancement of nanofluids. International Journal of heat and fluid flow, 21(1):58-64.

[12] Yimin X, Roetzel W. (2000) Conceptions for heat transfer correlation of nanofluids. International Journal of heat and Mass transfer, 43(19):3701-3707.

[13] Keblinski P, Phillpot SR, Choi SU, Eastman JA. (2002) Mechanisms of heat flow in suspensions of nano-sized particles (nanofluids). International journal of heat and mass transfer, 45(4):855-863.

[14] Wang X, Xu X, Choi SU. (1999) Thermal conductivity of nanoparticle-fluid mixture, Journal of Thermophysics and Heat Transfer, 13(2):474-480.

[15] Pak BC, Cho YI. (1998) Hydrodynamic and heat transfer study of dispersed fluids with submicron metallic oxide particles. Experimental Heat Transfer an International Journal, 11(2):151-170.

[16] Li Q, Xuan Y. (2002) Convective heat transfer and flow characteristics of $\mathrm{Cu}$-water nanofluid. Science in China Series E: Technological Sciences, 45(4):408-416.

[17] Li Q, Xuan Y, and Wang J. (2003) Investigation on convective heat transfer and flow features of nanofluids. Journal of Heat transfer, 125(2):151-155.

[18] Sankar N, Mathew N, Sobhan C B. (2008) Molecular dynamics modeling of thermal conductivity enhancement in metal nanoparticle suspensions. International Communications in Heat and Mass Transfer, 35(7):867-872.

[19] Hao ZN, Zhao R, Wang LR. (2005) Analyses of Physical Mechanism and Numerical Simulation for micro-convection Enhancement in the Solid-Liquid Two Phase Flow, Journal of Engineering Thermophysics, 26(1):656-658.

[20] Khaled A, Vafai K. (2005) Heat transfer enhancement through control of thermal dispersion effects. International Journal of Heat and Mass Transfer, 48(11):2172-2185.

[21] Dongsheng W, Ding Y. (2004) Experimental investigation into convective heat transfer of nanofluids at the entrance region under laminar flow conditions. International journal of heat and mass transfer, 47(24):5181-5188.

[22] Maïga EB, Sidi, Nguyen CT, Galanis N, Roy G, Maré T, Coqueux M. (2006) Heat transfer enhancement in turbulent tube flow using $\mathrm{Al}_{2} \mathrm{O}_{3}$ nanoparticle suspension. International Journal of Numerical Methods for Heat \& Fluid Flow, 16(3):275-292.

[23] Rostamani M, Hosseinizadeh SF, Gorji M, Khodadadi JM. (2010) Numerical study of turbulent forced convection flow of nanofluids in a long horizontal duct considering variable properties. International Communications in Heat and Mass Transfer, 37(10):1426-1431.

[24] Mokhtari R, Talebi F, Rafee R, Shariat M. (2015) Numerical Study of Pressure Drop and Thermal Characteristics of $\mathrm{Al}_{2} \mathrm{O}_{3}$-Water Nanofluid Flow in Horizontal Annuli. Heat Transfer Engineering 36(2):166-177. 
[25] Celik H, Mobedi M, Manca O, Buonomo B. (2018) Enhancement of Heat Transfer in Partially Heated Vertical Channel Under Mixed Convection by Using $\mathrm{Al}_{2} \mathrm{O}_{3}$ Nanoparticles. Heat Transfer Engineering, 39(3): 229-240.

[26] Battez A, Hernández R, González JL, Fernández D, Machado A, Chou R, Riba J. (2008) $\mathrm{CuO}, \mathrm{ZrO}_{2}$ and $\mathrm{ZnO}$ nanoparticles as antiwear additive in oil lubricants. Wear, 265(3):422428.

[27] Wu YY, Tsui WC, Liu TC. (2007) Experimental analysis of tribological properties of lubricating oils with nanoparticle additives. Wear, 262(7):819-825.

[28] Saeedinia M, Akhavan-Behabadi MA, Razi P. (2012) Thermal and rheological characteristics of $\mathrm{CuO}-\mathrm{Base}$ oil nanofluid flow inside a circular tube. International Communications in Heat and Mass Transfer, 39(1):152-159.

[29] Anoop KB, Sundararajan T, Das S K. (2009) Effect of particle size on the convective heat transfer in nanofluid in the developing region. International journal of heat and mass transfer, 52(9):2189-2195.

[30] Moraveji M, Darabi M, Haddad MH, Davarnejad R. (2011) Modeling of convective heat transfer of a nanofluid in the developing region of tube flow with computational fluid dynamics. International communications in heat and mass transfer, 38(9):1291-1295.

[31] Pak BC, Cho YI. (1998) Hydrodynamic and heat transfer study of dispersed fluids with submicron metallic oxide particles. Experimental Heat Transfer an International Journal, 11(2):151-170.

[32] Brinkman HC. (1952) The viscosity of concentrated suspensions and solutions. The Journal of Chemical Physics, 20(4):571-571.

[33] Patel HE, Sundararajan T, Pradeep T, Dasgupta T, Dasgupta N, Das SK. (2005) A microconvection model for thermal conductivity of nanofluids. Pramana, 65(5):863-869.

[34] Santra AK, Sen S, Chakraborty N. (2009) Study of heat transfer due to laminar flow of copper-water nanofluid through two isothermally heated parallel plates. International Journal of Thermal Sciences 48(2):391-400.

[35] Saeedinia M, Akhavan-Behabadi M A, and Razi P. (2012) Thermal and rheological characteristics of $\mathrm{CuO}-\mathrm{Base}$ oil nanofluid flow inside a circular tube. International Communications in Heat and Mass Transfer, 39(1):152-159.

[36] Murshed SMS , Leong KC, Yang C. (2008) Investigations of thermal conductivity and viscosity of nanofluids. International Journal of Thermal Sciences, 47(5):560-568.

[37] Li S, Eastman JA. (1999) Measuring thermal conductivity of fluids containing oxide nanoparticles. Journal of Heat Transfer, 121(2):280-289.

[38] Eastman JA, Choi SUS, Li Sh, Yu W, Thompson LJ. (2001) Anomalously increased effective thermal conductivities of ethylene glycol-based nanofluids containing copper nanoparticles. Applied physics letters, 78(6):718-720.

[39] Li Q, Xuan Y, Wang J. (2003) Investigation on convective heat transfer and flow features of nanofluids. Journal of Heat transfer, 125(2):151-155.

[40] Jung JY, Oh HS, Kwak HY. (2009) Forced convective heat transfer of nanofluids in microchannels. International Journal of Heat and Mass Transfer, 52(1):466-472. 